\title{
Late renal recovery after treatment over 1 year post-onset in an atypical hemolytic uremic syndrome: a case report
}

\author{
Yusuke Kuroki $^{1 *}$ D, Koji Mitsuiki ${ }^{1}$, Kaneyasu Nakagawa ${ }^{1}$, Kazuhiko Tsuruya ${ }^{2}$, Ritsuko Katafuchi ${ }^{3}$, Hideki Hirakata ${ }^{1}$ \\ and Toshiaki Nakano ${ }^{4}$
}

\begin{abstract}
Background: Atypical hemolytic uremic syndrome (aHUS) is a life-threatening disease that leads to end-stage kidney disease if only a poor response to plasma exchanges (PEs) or eculizumab therapy is achieved.

Case presentation: A 58-year-old Japanese man presented with thrombocytopenia, anemia, and kidney failure requiring dialysis without any underlying disease. A kidney biopsy revealed marked mesangiolysis in all glomeruli, compatible with thrombotic microangiopathy (TMA). Based on the positive anti- factor $\mathrm{H}$ antibody and negative result for secondary TMA, we diagnosed him as aHUS. Despite eculizumab administration after eight sessions of PE, neither platelet normalization nor kidney recovery was achieved. Eight months later, we discontinued eculizumab therapy due to anaphylactic reaction. At 15 months after the onset of TMA, his platelet count increased gradually from 40 to $150 \times 10^{3} / \mu \mathrm{L}$ with a decreased serum creatinine level and increased urine output, eventually allowing the withdrawal of dialysis therapy. A second kidney biopsy showed mesangial widening compatible with the healing of TMA.
\end{abstract}

Conclusions: This case indicates that aHUS with PEs and eculizumab therapy has the potential for renal recovery even if over 1 year has passed.

Keywords: Atypical hemolytic uremic syndrome, Mesangiolysis, Late renal recovery, Platelet normalization, Eculizumab

\section{Background}

The pathophysiology of thrombotic microangiopathy (TMA) has been described as consumptive thrombocytopenia, microangiopathic hemolytic anemia, and a manifestation of end-organ ischemia such as kidney failure [1]. Thrombotic thrombocytopenic purpura (TTP) is defined as decreased von Willebrand factor cleaving protease (a disintegrin-like and metalloproteinase with thrombospondin type 1 motifs 13; ADAMTS13)

\footnotetext{
* Correspondence: kuroki.yusuke.ge@mail.hosp.go.jp

${ }^{1}$ Nephrology \& Dialysis Center, Japanese Red Cross Fukuoka Hospital, 3-1-1, Ogusu, Minami-ku, Fukuoka 815-8555, Japan

Full list of author information is available at the end of the article
}

activity [2]. However, it is sometimes difficult to distinguish TMA from other diseases by only the clinical presentation and laboratory data. A kidney biopsy is indicated to confirm the diagnosis of TMA and evaluate the patient's prognosis, although it is difficult to perform a kidney biopsy in patients with thrombocytopenia [3]. The pathological findings of TMA are characterized by fibrin or platelet thrombi in the glomerular capillary lumina and arterioles, thickening of the capillary wall and arterioles, mesangiolysis, and extensive widening of the subendothelial space due to endothelial injury $[4,5]$.

Most cases of hemolytic uremic syndrome (HUS) are caused by a Shiga toxin-producing Escherichia coli

(C) The Author(s). 2020 Open Access This article is licensed under a Creative Commons Attribution 4.0 International License, which permits use, sharing, adaptation, distribution and reproduction in any medium or format, as long as you give appropriate credit to the original author(s) and the source, provide a link to the Creative Commons licence, and indicate if changes were made. The images or other third party material in this article are included in the article's Creative Commons licence, unless indicated otherwise in a credit line to the material. If material is not included in the article's Creative Commons licence and your intended use is not permitted by statutory regulation or exceeds the permitted use, you will need to obtain permission directly from the copyright holder. To view a copy of this licence, visit http://creativecommons.org/licenses/by/4.0/. The Creative Commons Public Domain Dedication waiver (http://creativecommons.org/publicdomain/zero/1.0/) applies to the data made available in this article, unless otherwise stated in a credit line to the data. 
(STEC) infection [6]. HUS without a STEC infection is classified as atypical HUS (aHUS), resulting from a dysregulation of an alternative complement pathway due to genetic abnormalities or other unknown reasons [7]. Activation of the complement system eliminates the thromboresistance function of endothelial cells, leading to systemic thrombosis. Over $50 \%$ of patients with aHUS will never recover kidney function; the response rate to the treatment differs with each genetic abnormality [8].

Eculizumab, a humanized monoclonal antibody that blocks the cleavage of complement 5 , is effective in aHUS [9], however some cases for which eculizumab was not effective have been reported [10]. The optimal schedule for the discontinuation of eculizumab therapy in responsive cases was recently discussed [11], but a schedule for poor-response cases has not been established.

Here we describe the case of a patient who suddenly developed aHUS with kidney failure requiring hemodialysis, after 15 months of hemodialysis therapy renal recovery with platelet normalization was confirmed, and the patient's hemodialysis was then discontinued.

\section{Case presentation}

A 58-year-old Japanese man was admitted to our hospital with the complaints of fever, pedal edema and facial puffiness that had begun 6 days before his admission. Six months earlier, his annual medical checkup showed normal blood pressure, no proteinuria, and an estimated glomerular filtration rate of $68.2 \mathrm{~mL} / \mathrm{min} / 1.73 \mathrm{~m}^{2}$. He had no history of loose stool, diarrhea or consumption of uncooked meat. He had no similar history including his family such as impaired kidney function. He was not currently taking any medications, health foods or supplements. His work and hobbies did not expose him to radiation or harmful substances, and he did not use recreational drugs.

On admission, he was conscious and had facial puffiness and bilateral pitting pedal edema. His blood pressure was 150/80 $\mathrm{mmHg}$. His urine examination showed proteinuria and hematuria with a urinary protein to creatinine ratio (UP/UCr) of $1.2 \mathrm{~g} / \mathrm{g}$ Cr. This $\mathrm{UP} / \mathrm{UCr}$ remained at $0.5-1.2 \mathrm{~g} / \mathrm{g} \quad \mathrm{Cr}$ after admission. His hemoglobin and platelet count declined within 2 weeks from 10.3 to $6.9 \mathrm{~g} / \mathrm{dL}$ and from 106 to $48 \times 10^{3} / \mu \mathrm{L}$, respectively. His albumin level was $3.0 \mathrm{~g} / \mathrm{dL}$, and decreased to $2.2 \mathrm{~g} / \mathrm{dL}$. The LDH level was $296 \mathrm{IU} / \mathrm{L}$, and increased to 341 on the 4th day. The LDH level remained in the range of 263-341 IU/L. His haptoglobin level was 36 $\mathrm{mg} / \mathrm{dL}$, which was the lower limit of the normal range. Peripheral blood smears indicated that $3-5 \%$ of red blood cells were schistocytes. Serum levels of complement 3 and 4 were within normal ranges. Other immunological tests including anti-nuclear antibody, anti-dsDNA antibody, myeloperoxidase anti-neutrophil cytoplasmic antibody, proteinase 3 anti-neutrophil cytoplasmic antibody, anti-glomerular basement membrane antibody and anti-lipopolysaccharide antibody showed no abnormalities. Both the direct and indirect erythrocytes antiglobulin tests were negative. Examination of plasma protein fractionation showed no monoclonal gammopathy.

The patient's serum creatinine level rapidly increased within 3 weeks from 1.6 to $4.8 \mathrm{mg} / \mathrm{dL}$. A kidney biopsy showed marked mesangiolysis and subendothelial swelling in 16 of 18 glomeruli contained in the sections, with the remaining 2 glomeruli being obliterated by global sclerosis (Fig. 1). Any thrombi, fibrinoid necrosis and hemoglobin casts were not identified. By immunofluorescence, immunoglobulin, complement and fibrinogen were all negative. These findings were compatible with the definition of TMA. The patient's ADAMTS13 activity decreased to $30 \%$ with negative ADAMTS13 inhibitor but not to a level as low as that observed in TTP.

The result of the laboratory work-up for secondary TMA was negative such as anti-phospholipid antibody syndrome, scleroderma, malignant hypertension, human immunodeficiency virus infection and homocysteinemia. In regard to etiologic analyses, no gene mutation such as $C F H, M C P, C F I, T H B D, C 3$ and $C F B$ was identified. Anti-factor $\mathrm{H}$ antibody was detected by a Western blotting analysis and an enzyme-linked immunosorbent assay (ELISA) with a titer of $76.9 \mathrm{AU} / \mathrm{mL}$. This level was not as high as the levels in other anti-factor $\mathrm{H}$ antibodypositive cases. However, because both Western blotting and ELISA were positive, we concluded that the patient was anti-factor $\mathrm{H}$ antibody-positive. Although hemolytic assay of sheep erythrocytes was negative of $9.6 \%$ and complement factor $\mathrm{H}$-related (CFHR) proteins 1 and 3 were not deleted, it seemed likely that this case was antifactorH antibody-associated aHUS.

Plasma exchanges (PEs) and hemodialysis therapy were started on the 11th day after the patient's admission. After eight PEs, we initiated treatment with eculizumab $900 \mathrm{mg} /$ week for 4 weeks and after that every other week (Fig. 2). As his kidney function deteriorated, his urine volume gradually decreased until he became oliguric when starting hemodialysis. Soon after starting hemodialysis, he became anuric. The hematologic abnormality and kidney failure requiring dialysis persisted. The platelet count remained $40 \times 10^{3} / \mu \mathrm{L}$. After 8 months of eculizumab administration, the patient suddenly developed a generalized rash with itching and slight dyspnea during the eculizumab administration. Because an anaphylactic reaction was suspected, we therefore discontinued the maintenance eculizumab therapy with his consent. 


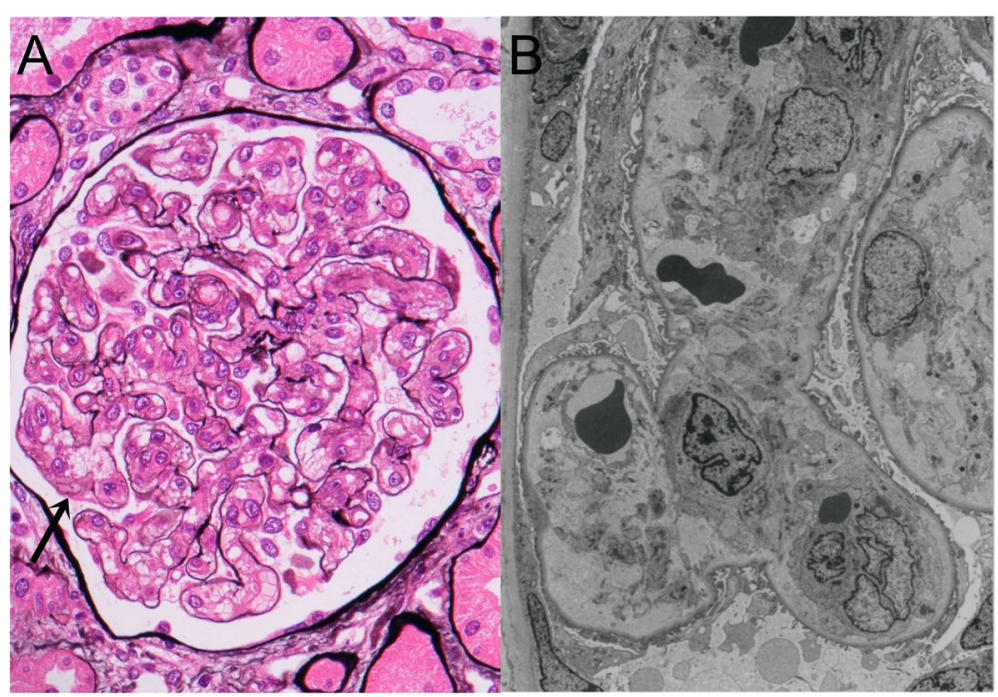

Fig. 1 a Light microscopy: Marked mesangiolysis was seen in all glomeruli. An unanchored dilated capillary had developed as result of the mesangiolysis (arrow). No fibrin or platelet thrombi were observed in the capillary lumina (Periodic acid-methenamine-silver stain, $\times 400$ ). $\mathbf{b}$ Electron microscopy: Widening of the subendothelial space and swelling of the endothelial cells resulted in thickening of the capillary wall, leading to narrowing of the capillary loop. Extravasations of red blood cells to the subendothelial space were seen. $(\times 5750)$

We performed an analysis of $C 5$ gene for his poor response to eculizumab, because its single missense heterozygous mutation causes a poor response to eculizumab in Japanese patients with paroxysmal nocturnal hemoglobinuria (PNH) [12]. However, the analysis did not detect this mutation.

At 15 months after the onset of aHUS, the patient's platelet count had increased gradually from 40 to $150 \times$ $10^{3} / \mu \mathrm{L}$. At the same time, the serum creatinine level before the hemodialysis session had declined with increased urine output despite the persistence of anuria after starting dialysis (Fig. 2). We were able to discontinue dialysis therapy, and his creatinine level eventually declined to $1.7 \mathrm{mg} / \mathrm{dL}$.

We performed a second kidney biopsy and found that mesangiolysis markedly decreased. Mesangiolysis and subendotherial swelling with double contour of the glomerular basement membrane were only segmentally

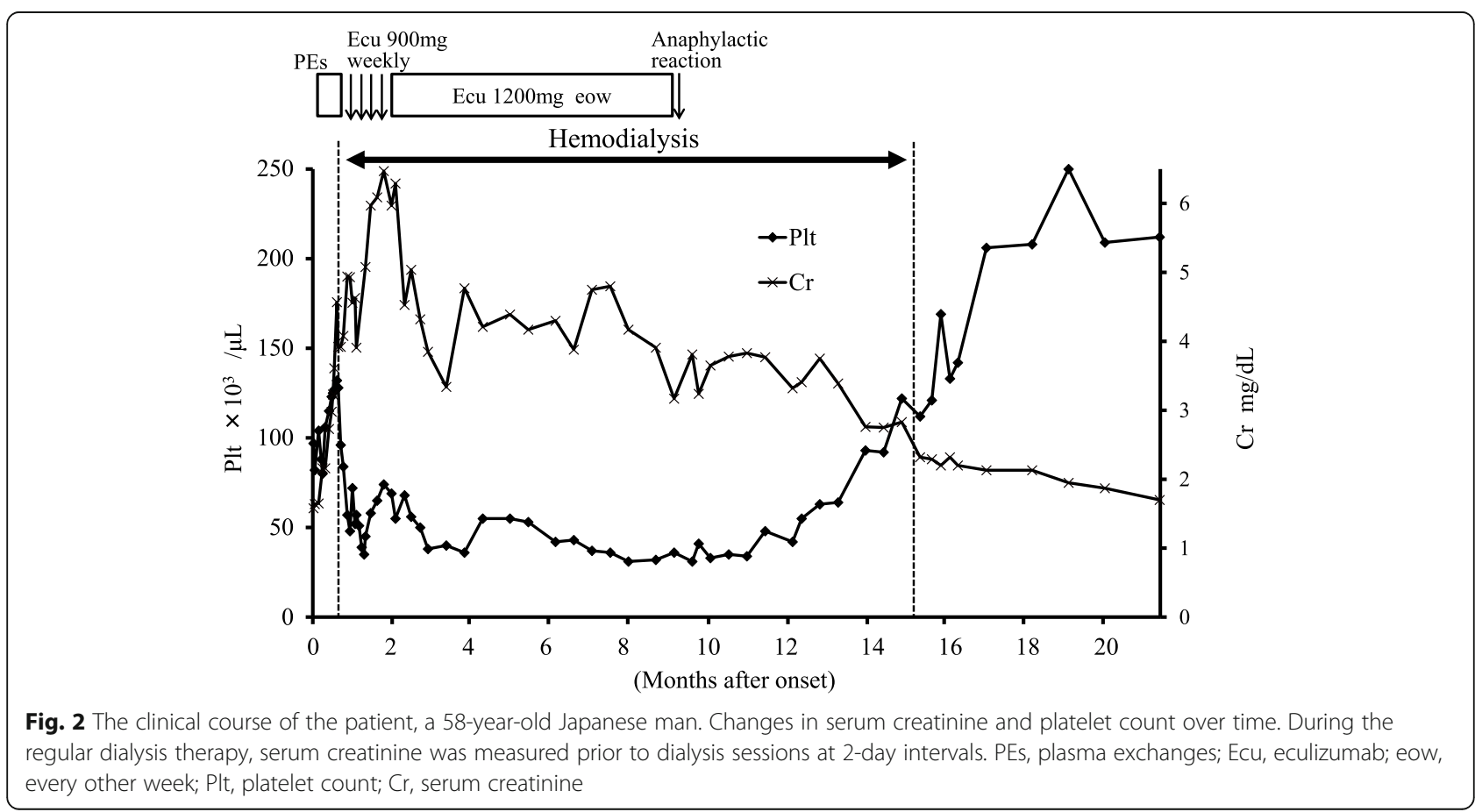


observed in some glomeruli. Mesangial widening due to increase in matrix was also observed in most glomeruli (Fig. 3). These findings were compatible with the healing stage of TMA.

Thus, our patient developed aHUS requiring dialysis with positive anti-factor $\mathrm{H}$ antibody and negative CFHR protein 1 and 3, and the aHUS did not improve rapidly despite treatment with PEs and eculizumab. However, 15 months later he had a recovery of kidney function with platelet normalization and his dialysis therapy was discontinued.

\section{Discussion and conclusion}

It is suspected that approximately $60 \%$ of aHUS cases are caused by a gene mutation in complement system [7] and that 5\% of the cases are due to anti-factor $\mathrm{H}$ antibody [13]. The development of anti- factor $\mathrm{H}$ antibody is strongly associated with deletion of both CFHR proteins 1 and 3, which are CFHR proteins that bind to the central complement component C3b [14], coding for proteins showing sequence and structural homology to factor $\mathrm{H}$ in close proximity to $\mathrm{CFH}$ gene [15]. This deletion results from genomic rearrangement in $\mathrm{CFH}-\mathrm{CFHR}$ region. In our patient, anti-factor $\mathrm{H}$ antibody was detected by a Western blotting analysis and ELISA despite no deletion of CFHR proteins 1 and 3 protein. Moore et al. reported that patients with CFHR protein 1 deletion had 0 copy number of CFHR1 and patients with CFHR protein 1 had a normal copy number of CFHR 1 [16]. Considering the above findings, it seemed likely that this case was anti-factor $\mathrm{H}$ antibody associated
aHUS without abnormality of $C F H-C F H R 1-5$ genomic region.

In our patient, eculizumab improved neither the platelet normalization nor the kidney recovery despite its administration 5 weeks after the onset. Furthermore, our patient showed negative hemolytic assay of sheep erythrocyte. These findings suggest that the development of aHUS may be resulted from another mechanism in addition to anti factor $\mathrm{H}$ antibody. Fakhouri et al. reported that causes of poor response to eculizumab were severe unrecognized pathologic features of renal TMA, gene abnormalities carrying a high risk of end-stage renal disease, a delay in the initiation of eculizumab, and a relatively short duration of eculizumab treatment [10]. It is possible that an unrecognized genetic mutation or pathophysiology was the cause of our patient's poor response to treatment. Further, earlier administration might have led to a better clinical course, though it took time to exclude TMA other than aHUS.

We did not administer immunosuppressive therapy for anti-factor $\mathrm{H}$ antibody. Several months had already passed by the time we concluded that the patient was positive for anti-factor $\mathrm{H}$ antibody. The anti-factor $\mathrm{H}$ antibody-related HUS showed a good response to treatment in the short term, but a poor renal outcome over the long term [17]. We considered that it was hopeless to recover kidney function due to the amount of time passed since the development of ESKD. Immunosuppressive medications were considered too risky in terms of immunocompromise, and so they were not administered.

In terms of PNH, Japanese patients with a single missense $\mathrm{C} 5$ heterozygous mutation have shown a poor

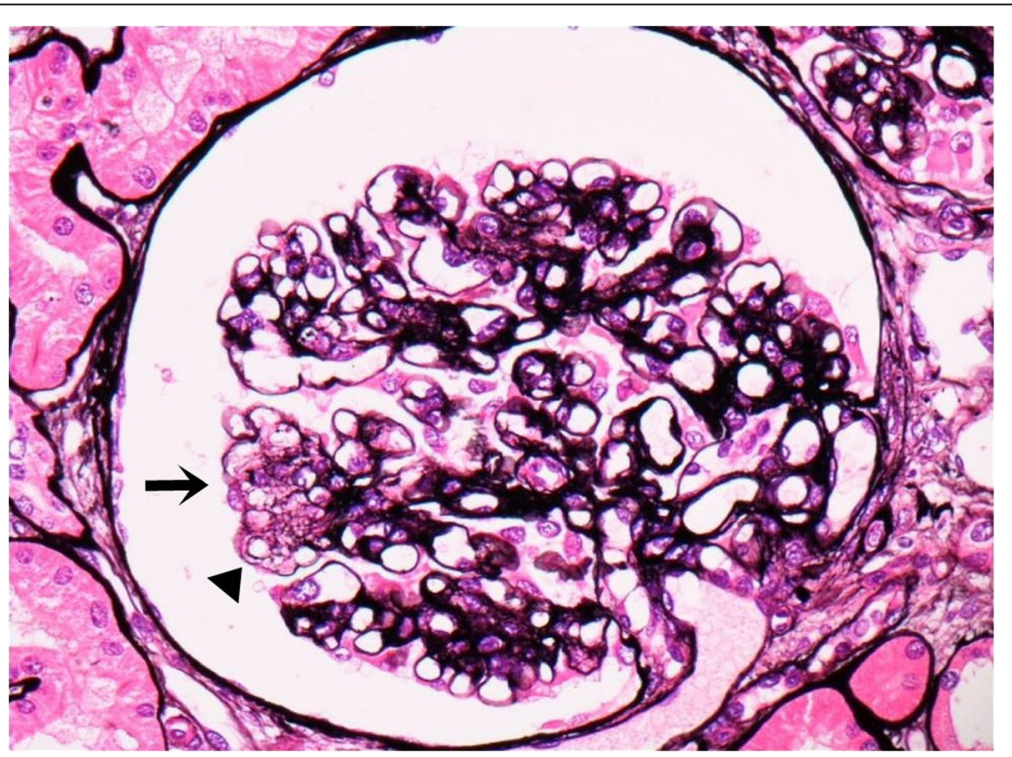

Fig. 3 Light microscopy: The glomeruli showed mesangial widening and thick capillary walls. Mesangiolysis (arrow) and subendotherial swelling with double contour (arrowhead) were segmentally seen in some glomeruli. (Periodic acid-methenamine-silver stain, $\times 400$ ) 
response to eculizumab [12]. The prevalence of this polymorphism with $\mathrm{PNH}(3.2 \%)$ is similar to that among healthy Japanese people (3.5\%) [12]. We therefore speculated that our patient might have a polymorphism of C5 gene, but it was not identified. Although this polymorphism was not detected in the present case, unidentified gene abnormalities may be related to no rapid response to eculizumab.

Kidney recovery with platelet normalization occurred more than 1 year after the onset of aHUS in our patient. To our knowledge, among the reports of treatmentresistant aHUS patients requiring dialysis, there has been no reports of cases with kidney recovery years later, allowing dialysis discontinuation. In a trial examining an adult aHUS population treated with eculizumab, $73 \%$ showed a complete TMA response with eculizumab and $79 \%$ discontinued dialysis during eculizumab treatment [18]. However, the poor-response cases in that trial needed dialysis therapy. In this case, it is possible that the 8 months of eculizumab therapy protected his kidneys and influenced his subsequent recovery, although he showed a poor response just after eculizumab administration. In light of this case, the timing of eculizumab discontinuation should be considered not only in rapid responsive cases, but also in poor-response cases.

In conclusion, this case indicates that aHUS has the potential for renal recovery with platelet normalization even over 1 year post onset. This recovery may be associated with PEs and eculizumab administration. Clinicians should thus keep in mind the possibility of renal recovery many months later.

\begin{abstract}
Abbreviations
TMA: Thrombotic microangiopathy; TTP: Thrombotic thrombocytopenic purpura; ADAMTS13: A disintegrin-like and metalloproteinase with thrombospondin type 1 motifs 13; HUS: Hemolytic uremic syndrome; STEC: Shiga toxin-producing Escherichia coli; aHUS: atypical hemolytic uremic syndrome; ELISA: Enzyme-linked immunosorbent assay; CFHR: Complement factor $\mathrm{H}$ related; PEs: Plasma exchanges; PNH: Paroxysmal nocturnal hemoglobinuria $(\mathrm{PNH})$
\end{abstract}

\section{Acknowledgements}

We thank Drs. Yoko Yoshida and Yoshihiro Fujimura (Nara Medical University) for analysis of anti-factor $\mathrm{H}$ antibody and CFHR proteins, and Dr. Hideki Kato (The University of Tokyo) for analysis of anti-factor $\mathrm{H}$ antibody. We also thank Dr. Toshiyuki Miyata (National Cerebral and Cardiovascular Center) for the complement gene analysis and Dr. Junichi Nishimura (Osaka University) for the C5 gene analysis.

\section{Authors' contributions}

Y.K. designed the study, analyzed the data, and drafted the manuscript. Y.K. and K.N. contributed to data acquisition. K.N. and R.K. contributed to the pathological diagnosis for kidney biopsies. K.M., K.T., R.K., H.H. and T.N. revised the article for important intellectual content. All authors contributed to the drafting of the manuscript, and approved the final version of the manuscript.

\section{Funding}

No funding was received specifically for this work.

\section{Availability of data and materials}

The datasets used and/or analyzed during the current study available from the corresponding author on reasonable request.

\section{Ethics approval and consent to participate}

Not applicable.

\section{Consent for publication}

Written informed consent was obtained from the patient for publication of this Case Report and any accompanying images. A copy of the written consent is available for review by the Editor of this journals.

\section{Competing interests}

The authors declare that they have no competing interests.

\section{Author details}

${ }^{1}$ Nephrology \& Dialysis Center, Japanese Red Cross Fukuoka Hospital, 3-1-1, Ogusu, Minami-ku, Fukuoka 815-8555, Japan. ²Department of Nephrology, Nara Medical University, Nara, Japan. ${ }^{3}$ Division of Nephrology, National Hospital Organization Fukuokahigashi Medical Center, Koga, Japan. ${ }^{4}$ Department of Medicine and Clinical Science, Graduate School of Medical Sciences, Kyushu University, Fukuoka, Japan.

Received: 10 March 2020 Accepted: 17 June 2020

Published online: 22 June 2020

\section{References}

1. Barbour T, Johnson S, Cohney S, Hughes P. Thrombotic microangiopathy and associated renal disorders. Nephrol Dial Transplant. 2012;27:2673-85.

2. Furlan M, Robles R, Solenthaler M, Wassmer M, Sandoz P, Lämmle B. Deficient activity of von Willebrand factor-cleaving protease in chronic relapsing thrombotic thrombocytopenic purpura. Blood. 1997;89:3097-103.

3. Campistol JM, Arias M, Ariceta G, Blasco M, Espinosa M, Grinyó JM, Praga M, Torra R, Vilalta R, Rodríguez de Córdoba S. An update for atypical haemolytic uraemic syndrome: diagnosis and treatment. A consensus document. Nefrologia. 2013;18(33):27-45.

4. Laszik ZG, Kambham N, Silva FG. Thrombotic Microangiopathies. In: Jennette JC, Olson JL, Silva FG, D'Agati VD, editors. Heptinstall's pathology of the kidney. 7th ed. Philadelphia: Wolters Kluwer; 2015. p. 739-814.

5. Morita T, Yamamoto T, Churg J. Mesangiolysis: an update. Am J Kidney Dis. 1998;31:559-73.

6. Karmali MA, Steele BT, Petric M, Lim C. Sporadic cases of haemolyticuraemic syndrome associated with faecal cytotoxin and cytotoxinproducing Escherichia coli in stools. Lancet. 1983;1(8325):619-20.

7. Noris M, Remuzzi G. Hemolytic uremic syndrome. J Am Soc Nephrol. 2005; 16:1035-50.

8. Fremeaux-Bacchi $V$, Fakhouri F, Garnier A, Bienaimé F, Dragon-Durey MA, Ngo S, Moulin B, Servais A, Provot F, Rostaing L, Burtey S, Niaudet $P$, Deschênes G, Lebranchu Y, Zuber J, Loirat C. Genetics and outcome of atypical hemolytic uremic syndrome: a nationwide French series comparing children and adults. Clin J Am Soc Nephrol. 2013;8:554-62.

9. Legendre CM, Licht C, Muus P, Greenbaum LA, Babu S, Bedrosian C, Bingham C, Cohen DJ, Delmas Y, Douglas K, Eitner F, Feldkamp T, Fouque D, Furman RR, Gaber O, Herthelius M, Hourmant M, Karpman D, Lebranchu Y, Mariat C, Menne J, Moulin B, Nürnberger J, Ogawa M, Remuzzi G, Richard T, Sberro-Soussan R, Severino B, Sheerin NS, Trivelli A, Zimmerhackl LB, Goodship T, Loirat C. Terminal complement inhibitor eculizumab in atypical hemolytic-uremic syndrome. N Engl J Med. 2013;368(23):2169-81.

10. Fakhouri F, Delmas $Y$, Provot F, Barbet C, Karras A, Makdassi R, Courivaud C, Rifard K, Servais A, Allard C, Besson V, Cousin M, Châtelet V, Goujon JM, Coindre JP, Laurent G, Loirat C, Frémeaux-Bacchi V. Insights from the use in clinical practice of eculizumab in adult patients with atypical hemolytic uremic syndrome affecting the native kidneys: an analysis of 19 cases. Am J Kidney Dis. 2014;63:40-8.

11. Ardissino G, Testa S, Possenti I, Tel F, Paglialonga F, Salardi S, Tedeschi S, Belingheri M, Cugno M. Discontinuation of eculizumab maintenance treatment for atypical hemolytic uremic syndrome: a report of 10 cases. Am J Kidney Dis. 2014;64(4):633-7.

12. Nishimura J, Yamamoto M, Hayashi S, Ohyashiki K, Ando K, Brodsky AL, Noji H, Kitamura K, Eto T, Takahashi T, Masuko M, Matsumoto T, Wano Y, Shichishima T, Shibayama H, Hase M, Li L, Johnson K, Lazarowski A, 
Tamburini P, Inazawa J, Kinoshita T, Kanakura Y. Genetic variants in C5 and poor response to eculizumab. N Engl J Med. 2014;13(370):632-9.

13. Dragon-Durey MA, Sethi SK, Bagga A, Blanc C, Blouin J, Ranchin B, André JL, Takagi N, Cheong HI, Hari P, Le Quintrec M, Niaudet P, Loirat C, Fridman WH, Frémeaux-Bacchi V. Clinical features of anti-factor $\mathrm{H}$ autoantibodyassociated hemolytic uremic syndrome. J Am Soc Nephrol. 2010;21:2180-7.

14. Skerka C, Chen Q, Fremeaux-Bacchi V, Roumenina LT. Complement factor H related proteins (CFHRs). Mol Immunol. 2013;56(3):170-80.

15. Jo'zsi M, Zipfel PF. Factor $\mathrm{H}$ family proteins and human diseases. Trends Immunol. 2008;29(8):380-7.

16. Moore I, Strain L, Pappworth I, Kavanagh D, Barlow PN, Herbert AP, Schmidt CQ, Staniforth SJ, Holmes LV, Ward R, Morgan L, Goodship TH, Marchbank KJ. Association of factor $\mathrm{H}$ autoantibodies with deletions of CFHR1, CFHR3, CFHR4, and with mutations in $\mathrm{CFH}, \mathrm{CFI}, \mathrm{CD} 46$, and $\mathrm{C} 3$ in patients with atypical hemolytic uremic syndrome. Blood. 2010;115(2):379-87.

17. Noris M, Remuzzi G. Atypical Hemolytic-Uremic Syndrome. N Engl J Med. 2009;361(17):1676-87.

18. Fakhouri F, Hourmant M, Campistol JM, Cataland SR, Espinosa M, Gaber AO, Menne J, Minetti EE, Provôt F, Rondeau E, Ruggenenti P, Weekers LE, Ogawa M, Bedrosian CL, Legendre CM. Terminal complement inhibitor eculizumab in adult patients with atypical hemolytic uremic syndrome: a single-arm, open-label trial. Am J Kidney Dis. 2016;68(1):84-93.

\section{Publisher's Note}

Springer Nature remains neutral with regard to jurisdictional claims in published maps and institutional affiliations.

Ready to submit your research? Choose BMC and benefit from:

- fast, convenient online submission

- thorough peer review by experienced researchers in your field

- rapid publication on acceptance

- support for research data, including large and complex data types

- gold Open Access which fosters wider collaboration and increased citations

- maximum visibility for your research: over $100 \mathrm{M}$ website views per year

At BMC, research is always in progress.

Learn more biomedcentral.com/submissions 